\title{
What do "Back-to-School" Computers have in Common with Health Education and Health Protection?
}

\author{
Adenike Bitto \\ East Stroudsburg University
}

\begin{abstract}
How to increase immunization levels in communities is a recurrent problem associated with missed opportunities. As communities gear-up for Back to School, health educators may encourage people to update their child, adolescent, and adult immunizations. Human herd immunity can protect communities from spread of infection, and an analogy is presented with "herd immunity for personal computers." Both computer and biological viruses spread faster when a large portion of the population is unprotected. Just as individuals should receive immunization shots to protect self and families; computer systems can be protected against nasty computer code by using current anti-virus programs to limit the spread of viruses, worms, and Trojan horses from one computer to another. How much more would individuals rather receive timely shots that help to preserve health? An ounce of prevention is worth a pound of cure.
\end{abstract}

(C)2005 Californian Journal of Health Promotion. All rights reserved.

Keywords: Back to School, herd immunity, age appropriate immunization, health education

This article invites readers to address today's topical issue. As health educators, we have an important role to prepare students, parents, and primary caregivers, as they organize for Back to School. Frantic visits to bookstores and office supply stores do not tell the whole story; there is more to be done to complete preparations and stock up on supplies for the fall semester and new academic year.

Health educators may consider working with local community members to recommend the implementation of health and personal computer (PC) protection, as a component of Back-toSchool preparations. Both computer and biological viruses spread faster when a large portion of the population is unprotected. Furthermore, August is National Immunization Awareness Month. Communities should seize this opportune moment and cue to action, to review and update children and adult's immunization status and records. On one hand, according to Thompson (2004), 15\% of adults do not believe in the efficacy of immunizations protection from certain diseases. Nevertheless, immunizations do work, as evidenced by the worldwide 1970's eradication of naturallyoccurring smallpox.

\section{Herd Immunity and Recommended Immunization Schedules}

Human herd immunity is the "resistance of a group to invasion and spread of an infectious agent, based on the immunity of a high proportion of individual members of the group (Fox, 1970; Mausner \& Bahn, 1974, p. 277).” In other words, ensuring that each child receives the complete age-appropriate immunization schedule will help to protect the community from spread of infection. Health educators can raise the question whether all kids' shots are upto-date including diphtheria, tetanus, pertussis, poliovirus, Haemophilus influenzae type b, measles, mumps, rubella, chickenpox-varicella, hepatitis B, Streptococcus pneumonia, and any other pertinent immunization against the common diseases of childhood. Additional vaccinations may be recommended in certain States or for selected high-risk subgroups of the population (CDC, 2005a; CDC, 2002; Pennsylvania Department of Health, 2005). Residents may check by visiting their local 
health center, health care provider, or the school nurse in their child's school district. Remember that in addition to their booster shots, adolescent college freshmen heading off to the dormitory on campus may need to receive immunization, specifically to protect them against meningitis (and influenza later on in the season)(CDC, 2005b; CDC, 2005c). For adults aged 19 years or older, the National Immunization Program recommends a good number of the immunizations listed above, plus hepatitis A (CDC, 2005d). Each family should consult their physician for advice.

\section{Comparing 'Herd Immunity for Personal Computers' and Shots for Biological Protection from Micro-organisms}

With some imagination, the concept of herd immunity can be expanded and applied to personal computers. Just as people receive immunization to protect them and their families, computer systems need to be protected against nasty computer code - 'viruses' and other threats. Clearly, computer experts appear to understand about 'herd immunity for computers'-as they counsel use of an up-to-date computer anti-virus program to limit the spread of viruses, worms, and Trojan horses from one computer to another. PC owners must constantly update virus definition software, in order to ensure continuous computer protection from malicious attacks. This is similar to ensuring that each person has an up-to-date immunization history. In either case, each immunized person or each personal computer with its anti-virus software helps to protect other members of the community from biological infection or computer infection, respectively. Think about it, if a particular computer is protected, then that is one less computer that can serve to spread destructive computer programs to other computers; it is likewise regarding biological spread of infection when many people already have their shots! Moreover, with Internet access, personal computers need a protective firewall installed against Web site intruders. Another concern relates to using parental controls to protect minors who access Internet Web sites.

\section{Summary and Recommendations - Update your immunization history}

The two main categories of prevention discussed in this article constitute "an ounce of prevention that is worth a pound of cure," namely - (1) preventative shots to protect people from biological infection that spreads from one person to the other, and could stop individuals from going about their daily business, including going to school/studying; and (2) anti-virus computer programs that preserve functional computers and keep people productive at health education, school and other work related assignments. For trainee health educators and others returning to school in the fall, these preventative strategies could prevent undue stress attached to a virusinfected computer that wipes out critical work and similar hazards. One main theme of health education is to promote actions that result in good health, and certainly, up-to date immunizations can contribute to this agenda. Yes, please consider adding these strategies to your overall Back-to-School plans and preparations. Among several sources of information, health educators may refer community to obtain free guides to reliable health information and safe web surfing, by visiting http://www.healthfinder.gov/kids.

\section{References}

Centers for Disease Control and Prevention. (2005a). Recommended childhood and adolescent immunization schedule, United States, 2005. Summary of the recommendations published by the advisory committee on immunization practices (ACIP). MMWR.

Centers for Disease Control and Prevention. (2005b). Prevention and control of meningococcal disease: Recommendations of the Advisory Committee on Immunization Practices (ACIP). MMWR, 54(RR-7), 1-21.

Centers for Disease Control and Prevention. (2005c). Prevention and control of influenza: Recommendations of the advisory committee on immunization practices (ACIP). MMWR, 54(RR-8). 
Centers for Disease Control and Prevention. (2005d). Recommended adult immunization schedule by age group and medical conditions. United States, 2003-2004. Summary of the recommendations published by the advisory committee on immunization practices (ACIP). MMWR 2005.

Centers for Disease Control and Prevention. (2002). General recommendations on immunization: recommendations of the advisory committee on immunization practices (ACIP) and the American Academy of Family Physicians (AAFP). MMWR, 51(RR-2), 1-44.

Fox, J. P., Hall, C. E. et al. (1970). Epidemiology: Man and disease. New York: Macmillan Publishing.

Mausner, J. S, and Bahn, A. K. (1974). Epidemiology: An introductory text. Philadelphia: W. B. Saunders Company.

Pennsylvania Department of Health. (2005). Pennsylvania school immunization requirements - 28 PA.CODE CH.23 (School Immunization). Retrieved, July 30, 2005, from http://www.dsf.health.state.pa.us

Thompson, D. (2004). If it's back to school, it's also vaccine time: Experts say the shots are a crucial weapon against disease. HealthDayNews, ScoutNews, LLC. Retrieved July 30, 2005, from http//www.healthfinder.gov

\title{
Author Note and Acknowledgements
}

A shorter version of this manuscript is under consideration for publication in our local newspaper, The Pocono Record, as a Weekly Professor column edited by Dr. Richard Wesp. The author appreciates Dr. Wesp's interest in this topic.

\author{
Author Information \\ Adenike Bitto, MD, MPH, DrPH, CHES \\ Associate Professor of Health \\ East Stroudsburg University \\ 200 Prospect Street \\ East Stroudsburg, PA 18301 \\ Ph: 570-422-3375 \\ E-Mail: abitto@po-box.esu.edu
}

